\title{
Promoting Knowledge Construction and Cognitive Development: A Case Study of Teacher's Questioning
}

\author{
Kelu Wang \\ College of Foreign Languages, Leshan Normal University, Sichuan, China \\ Xiaolin Wang \\ Faculty of Humanities and Foreign Languages, Xi'an University of Technology, Xi'an, China
}

\begin{abstract}
Teacher questioning is one of the indices of the quality of teaching. It plays an essential role in promoting students' knowledge construction and cognitive development through classroom interaction. In the meanwhile, teacher questioning reflects to what extent authority is shared between teacher and students. Through an analysis of teacher questions in an Intensive Reading class in a China university, this article investigates how language knowledge and authority relationship are co-constructed through the interaction between the teacher and students. It aims to identify the teaching methods embedded in the ways of teacher questioning that enables students to gain knowledge and reasoning ability.
\end{abstract}

Index Terms-teacher questioning, knowledge construction, cognitive development, authority relationship, communicative language teaching, task-based language teaching

\section{INTRODUCTION}

Teacher questioning is an important component of classroom talk. It plays a critical role in promoting students' meaning-making and cognitive engagement through classroom interaction. Teacher questioning may simply check students' understanding, seek for information, help students recall knowledge and experience, or even discourage them from articulating their thoughts by posing some "guest-what-is-in-my-mind" questions. Otherwise, teacher questioning can go beyond requiring a pre-determined short answer to assist students to construct knowledge, elicit students' ideas, and scaffold their reasoning (Chin, 2007).

On the other hand, teacher questioning reflects to what extent authority is shared between teacher and students. The kinds of questions that teachers ask show whether they treat "students' utterances, and their own statements as either 'thinking devices' or a means for transmitting information” (Nystrand, Gomoran, Kachur, \& Prendergast, 1997, p.9). Thereby, students are regarded as constructed knowers or received knowers (Belenky, Clinchy, Goldberger, \& Tarule, 1986). Teachers who treat students as constructed knowers are more likely to share authority with students, encourage them to contribute personal life experiences and feelings, and try to foster a sense of agency in knowledge construction; while teachers seeing students as received learners have a tighter control of authority and tend to transmit knowledge by asking some factual questions (Johnston, Woodside-Jiron, \& Day, 2001).

Teacher questioning is one of the indices of the quality of teaching. It is meaningful to examine teacher questions in the English classrooms for a better understanding of how teacher questions facilitate university students to construct language knowledge, develop productive thinking, and learn to value their own competence and experience in language learning. In addition, this kind of examination gives an insight into the teaching methods adopted by the teacher to achieve particular learning outcomes.

This essay, focusing on questioning-based discourse in one Intensive Reading class for English major students in tertiary education, investigates how language knowledge and authority relationship are co-constructed through the interaction between teacher and students. It aims to identify the teaching methods embedded in the ways of teacher questioning that enables students to gain knowledge, reasoning ability, and agency.

\section{THEORETICAL UNDERPINNING}

The theoretical orientation to this research on teacher questioning is sociolinguistic approach. The sociolinguistic perspective takes into account of specific purposes and local contingencies when a question is posed, and sees the question and feedback as part of a dynamic process that has an impact on subsequent ones and work cumulatively in fostering student learning. Carlsen suggested that three features of questions be considered when doing research on questioning in classrooms: "the context of questions, the content of questions, and the responses and reactions that teachers and students have to questions" (1991, p. 159). Hence, this study will examine teacher questions over a stretch of discourse, and explore how the questions in successive discourse build progressively on students' response and guide 
students towards constructing language knowledge.

\section{Methodology}

\section{A. Participants}

The lecturer is a 52 year-old female professor with 25 years' teaching experience. She has experience in giving lectures on Applied Linguistics, Discourse Analysis to graduate students, and Intensive Reading to undergraduates. The students attending the class are sophomores of English major in a key university in northwest China. There are 8 male students and 24 female students ranging from 20 to 22 years ago. They have 8 to 14 years' experience in English learning, with more than 2 years specifically for learning English as their major by the time of data collection.

\section{B. Data Collection}

The data was collected by video recording an Intensive Reading class. The lecturer and students were informed of the purpose of video recording, and all of them gave consent for video recording. The recorded lesson lasts 45 minutes, which is usually the length of a period in China.

\section{Data Analysis}

The video clip of the observed lesson was independently transcribed by the author and another researcher. The interrater reliability is $98.6 \%$. Since the focus on this study is on teacher questioning, only the spoken discourse is analyzed. Questions are defined in terms of their function rather grammatical form, because interrogative form alone does not make a question. For example, if the teacher answers his or her own question with no intention of inviting a response from students, then the utterance has the form of a question but the function of a statement. The analysis of questions will take into account the context, the content, and the responses and reactions to questions as suggested by Carlson (1991).

\section{RESULTS AND DisCUSSION}

The analysis of the classroom interaction between the teacher and students shows that different types of questions were used by the teacher in different stages of the lesson for particular purposes. In the episodes below, italic sentences are the original utterances in Chinese pin yin form, and the English translation is given within the square brackets [ ]. Three dots "..." indicate the omission of irrelevant words or sentences. "S" with a number refers to an identifiable student, and "Ss" refers to a group of students or the whole class. For the sake of convenience, teacher's questions are underlined.

\section{A. Opening up the Lesson and Introducing the Topic}

In Excerpt 1, the teacher opened up the lesson with an indication that students are going to report their research on paradox in this period, so she used factual questions "what is the function of paradox or definition?" and "In Chinese what does it mean?" to seek for information about the topic "paradox". As the definition and Chinese translation of paradox are somewhat fixed and within the teacher's knowledge scope, these questions invited for predetermined answers. Then speculative questions "And can you offer some examples?" and "Can you give us an example?" immediately followed to elicit answers building on content. In other words, students were invited to provide more information about the topic. Since the examples students gave are unknown to the teacher, the two questions are speculative questions with no predetermined answer. All of these questions are of lower-order cognitive level because students were asked to present some factual information, however, they are effective in opening up the lesson and introducing the topic.

\begin{tabular}{|c|c|}
\hline $\mathrm{T}$ & $\begin{array}{l}\text { And last time I didn't find enough time for you to present to report } \\
\text { what you have discovered through your research. So based on your } \\
\text { personal research, what is the function of paradox or definition? } \\
\text { And can you offer some examples? So one paradox. S1, so you } \\
\text { found your your notes, Okay? }\end{array}$ \\
\hline S1 & Paradox is apparently self-contradictory statement. \\
\hline Ss & \\
\hline $\mathrm{T}$ & $\begin{array}{l}\text { Okay. So that's the definition. In Chinese what does it mean? } \\
\text { Paradox. In Chinese what is the meaning? }\end{array}$ \\
\hline $\mathrm{S} 1$ & zi xiang mao dun [self-contraditary]. \\
\hline $\mathrm{T}$ & $\begin{array}{l}\text { zi xiang mao dun [self-contraditary]. Okay? Now anyone have } \\
\text { some kind of addition something to add up? Can you give us an } \\
\text { example? }\end{array}$ \\
\hline S1 & $\overline{\text { Example. Less is more. }}$ \\
\hline
\end{tabular}

\section{B. Scaffolding Students'Thinking}

Excerpt 2 is what happened after Excerpt 1 where S1 offered an example of paradox (less is more) under the 
teacher's request. Upon this example, the teacher opened up the participation opportunity for all the students by saying "Can anybody paraphrase it?". As to this question, the teacher possibly had had a pre-determined answer, but wanted to check whether students understand the denotation of this paradox. After one student gave a vague paraphrase "To get less to get more", the teacher did not make evaluation immediately, but repeated what the student said and further posed questions "What does that mean? What is the implied meaning?". By asking about the implied meaning, the teacher tried to move S2's idea forward. When S3 produced a wrong Chinese translation, the teacher did not negate her answer right away, but repeated it in a rising tone, indicating that this answer is problematic. The teacher's repetition successfully made S3 get suspicious about her own answer, and S3 sought confirmation from the teacher by asking " $b u$ shi ma [Isn't it right]?". Then the teacher delayed her evaluation, and used a rhetorical question "is it" as feedback, and then posed another question "So in your life have you been ever in such kind of situation". Here the teacher continued to build on students' thinking, explicitly requiring students to bring in their personal experience in understanding the paradox in question. This question is effective in provoking thought, as one student (S4) did contribute a good interpretation. What is laudable about the teacher's questioning is that she constantly adjusted questioning to accommodate students' contributions and responded to students' thinking in a neutral rather than evaluative manner. Moreover, when students' experiences are encouraged to be taken into classroom discourse, the authority of the teacher is partly shifted to the students. The teacher is not deemed as the only source of knowledge, and students are made to realize that they themselves can be the source of knowledge as well.

\begin{tabular}{|c|c|}
\hline $\mathrm{T}$ & Less is more. Can anybody paraphrase it? Less is more. \\
\hline S2 & To get less to get more. \\
\hline $\mathrm{T}$ & $\begin{array}{l}\text { To get less to get more? What does that mean? What is the implied } \\
\text { meaning? }\end{array}$ \\
\hline S3 & $\overline{\text { you she you de [The hand that gives gathers]. }}$ \\
\hline $\mathrm{T}$ & you she you de [The hand that gives gathers]? \\
\hline S3 & bu shi ma [Isn't it right]? \\
\hline Ss & $(($ Laugh $))$ \\
\hline $\mathrm{T}$ & $\begin{array}{l}\text { bu shi ma [Is it]? ((laugh)) Less is more. Yeah, that's really a good } \\
\text { example. Now think about it. Less is more. To to get less means to } \\
\text { get more. (3) Now use use your imagination to think about it! So in } \\
\text { your life have you been ever in such kind of situation? Have you } \\
\text { ever been in such kind of situation? Now S4. }\end{array}$ \\
\hline S4 & $\begin{array}{l}\text { I think this situation depends on different subjects. Such as if you } \\
\text { have less desire you may have more happiness. }\end{array}$ \\
\hline $\mathrm{T}$ & $\begin{array}{l}\text { If you have less desire of your life, if you do not desire so much, } \\
\text { you would feel happy, you are so satisfied with your present } \\
\text { situation. That might be a good interpretation. }\end{array}$ \\
\hline
\end{tabular}

\section{Throwing the Responsibility of Thinking Back to Students}

Teacher questioning plays a critical role in facilitating productive and higher-order thinking, and developing students' agency in learning. Excerpt 3 is an exclusive interaction between the teacher and S1. The successive discourse below displays how the teacher scaffolded the student's reasoning and helped him make meaning of the paradox "less is more". In this episode, S1, who offered the example "less is more", was enquired about his interpretation. When he failed to interpret this paradox and just pointed out that the sentence was full of connotations, the teacher adopted the strategy of posing "reflective toss" questions to guide him think further. Reflective toss refers to teacher questions that "“catch" the meaning of the student's prior utterance and 'throw' responsibility for thinking back to the students" (van Zee \& Minstrell, 1997, p. 229). The teacher started from asking about the student's own connotation; after the student gave a general answer "I think that is a kind of philosophy of life", the teacher threw the question back to him by asking "What kind of philosophy of life? Can you tell us?", which encouraged the student to elaborate on his previous answer and extend his opinions. Then S1 replied "It's a kind of attitude towards life", which is not specific enough to show his clear understanding of the paradox. On the basis of this, the teacher narrowed down the question and threw it back to the student again by asking "So do you think it's a good attitude or bad attitude?" and "Is it positive or negative?". The last two questions finally led S1 to understand that the paradox shows a positive attitude towards life. The teacher questioning may have expected student responses of greater complexity than what is displayed here, but S1's language proficiency may be a potential obstacle for him to produce more elaborated and complex answers as an EFL learner.

This episode is enough to show that teacher's questions need to build on students' offering and guide their thinking towards answers which are not merely guesses or displays of bits of knowledge but based on solid reasoning and evidence. In addition, by throwing the questions back to students, the teacher conveyed to them the message that they have responsibility for thinking and constructing knowledge, instead of counting on the teacher to transmit the knowledge. 


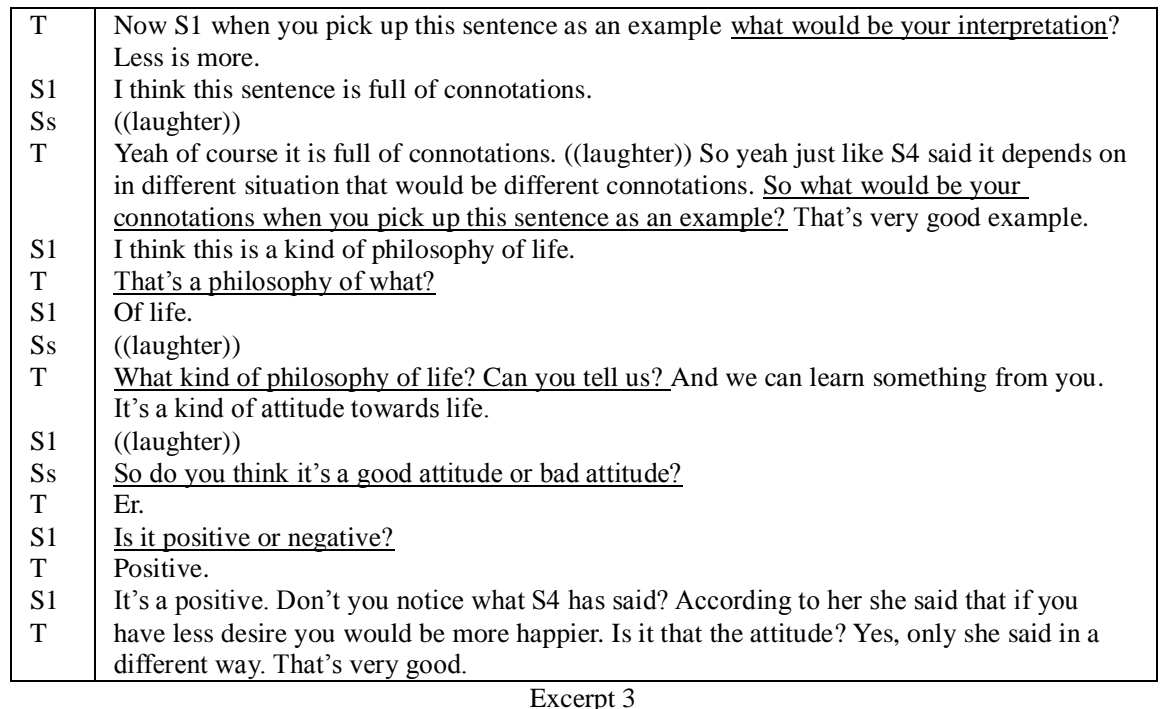

\section{Enabling Peer Evaluation}

Teacher questions can also make students facilitate each other in knowledge construction, and incorporate students' ideas into subsequent dialogue. The use of peer assessment in evaluating students' answer, in the episode below, enables students to learn from each other's answers and co-construct knowledge with each other in an accountable way. The authority is shared among the teacher and students, as the teacher plays the part of a facilitator in students' knowledge construction instead of knowledge giver.

In Excerpt 4, S4 provided another example "If you wish to preserve your secret, wrap it up in frankness", and the teacher stimulated students' thinking to find out its connotations. She first posed a speculative question "So what's the connotation?" to gather students' ideas. Then she avoided evaluation on S5's wrong translation, and threw the question back to all the students by asking them "Is that right?". This question allows the teacher to shift authority for evaluating answers from herself as the teacher (van Zee \& Minstrell, 1997) to all students who need to make sense of what their classmates say for the purpose of knowledge construction. Then the lesson diverged a short while from this question to student S6's responses to this question.

S6 proposed another interpretation "It's something like the public secret", which itself contains a paradox "public secret" that needs to be unpacked. Therefore, the teacher's next question focused on "public secret" and requested the student to explain what public secret means. Based on S6's explanation "If the secret is known in public so it's not secret at all", the teacher assisted him to think deeper with question "If everyone knows it, nobody will what?". This question gave clues to answer, and successfully guided S4 to arrive at a more mature understanding of public secret. What is salient in this episode is the teacher's flexibility in questioning as discussion proceeded. It is necessary that teachers take students' input seriously and adapt questions according to the constantly changing context, rather than strictly move through a series of questions in accordance with a planned agenda.

The divergence to "public secret", as an analogy to "wrap the secret up in frankness", facilitated other students' thinking and made S4 easily grasp the connotation of this paradox "If you wish to preserve your secret, wrap it up in frankness".

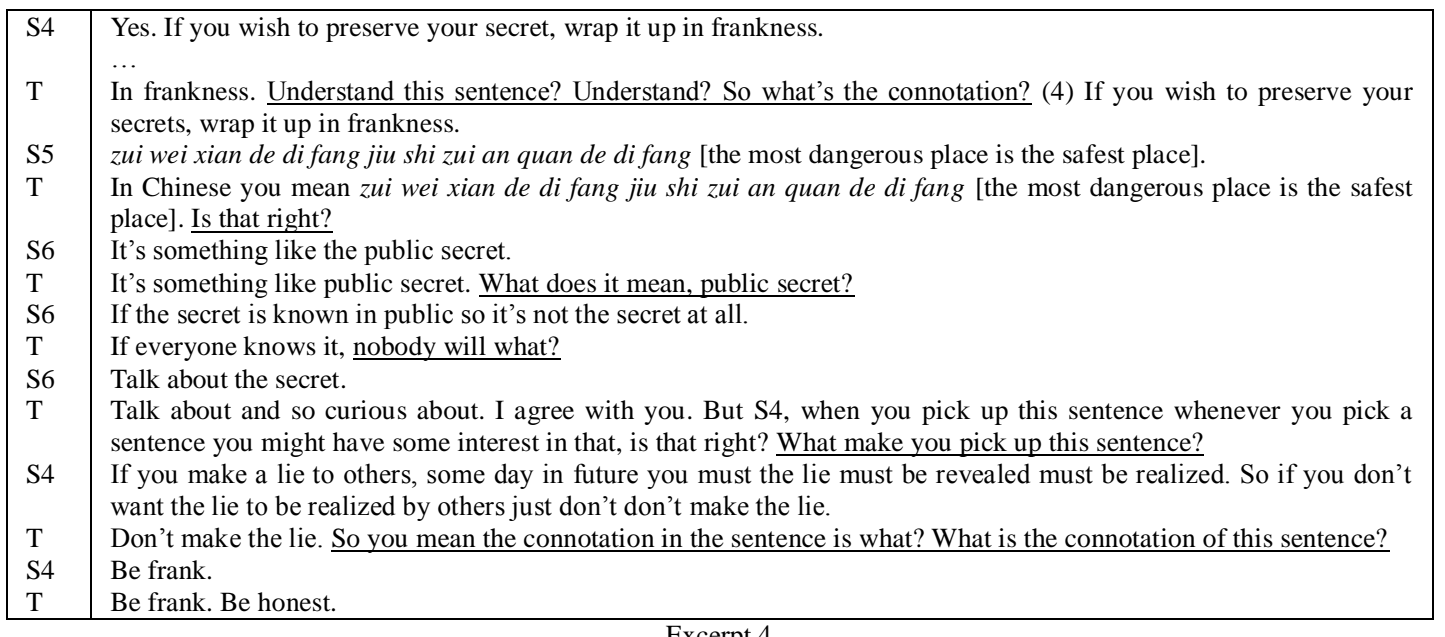




\section{E. Moving Students'Thinking towards a Higher Level}

The "interpretation-oriented" (Nystrand et al., 1997, p. 9) ways of questioning in this episode shows that the teacher is not just transmitting knowledge to students, but stimulating them to go beyond right-and-wrong answers (Nystrand et al., 1997) for a higher-level thinking. In Excerpt 5 below the teacher formulated questions to develop students' productive thinking and helped them make sense of the paradox "the child is the father to the man" in complexity and depth. Most of the questions were pitched at higher-order cognitive level. For instance, when S9 gave her connotation "Man can learn a lot from a child", the teacher proposed process questions "why" and "what men can learn a lot from child" to ask for explanation of their thinking. Then when S10 used vague words "some factors" in her explanation "Because child has some factors which are not indulged by the adults or and", the teacher threw the responsibility of clarifying this "some factors" back to her by asking "Yeah he may have some kind of". Although S10 did not give a specific explanation to "some factors", her short answer "pure" indicates that her thinking is on the right track, as evidenced by the teacher's elaboration followed. The teacher's abandonment of her "transmission-oriented" role helps students deem themselves as the source of knowledge, thus fostering students' agency and promoting their self-confidence.

\begin{tabular}{|c|c|}
\hline $\mathrm{T}$ & $\begin{array}{l}\text { Okay. Next one is very interesting. The child is the father the child } \\
\text { is the father to the man. What is the connotation? } \\
\text { Man can learn a lot from a child. }\end{array}$ \\
\hline S9 & Man can lean a lot from a child. Why? \\
\hline $\begin{array}{l}\mathrm{T} \\
\mathrm{S} 9\end{array}$ & $\begin{array}{l}\text { Some some maybe man has lost some personalities or some } \\
\text { characteristics of child. } \\
\text { But what is the philosophy contained in this sentence? Yeah man }\end{array}$ \\
\hline $\mathrm{T}$ & $\begin{array}{l}\text { can learn a lot form child. Why? Why man can lean a lot from } \\
\text { child? } \\
\text { To recover. }\end{array}$ \\
\hline $\begin{array}{l}\text { S9 } \\
\mathrm{T}\end{array}$ & $\begin{array}{l}\text { Yeah child is the father to a man. What she is right means man } \\
\text { means father can teach a lot of things. Is that right? And you can } \\
\text { learn a lot from child. Why? }\end{array}$ \\
\hline S10 & $\begin{array}{l}\text { Because child has some factors which are not indulged by the } \\
\text { adults or and. } \\
\text { Yeah he may have some kind of? }\end{array}$ \\
\hline $\mathrm{T}$ & Pure. \\
\hline $\begin{array}{l}\mathrm{S} 10 \\
\mathrm{~T}\end{array}$ & $\begin{array}{l}\text { Pure way of doing things pure way of thinking something that's } \\
\text { not influenced by the adult society. }\end{array}$ \\
\hline
\end{tabular}

\section{F. Teaching Methods Embedded in Teacher Questioning}

\section{Communicative-Language-Teaching-guided teacher questioning}

The analysis of teacher questioning above shows that the teacher-student interaction in the observed lesson is dialogic and interactive in the following ways: First of all, there were no predetermined answers for most of the teacher's questions. Thus, these questions "allow an indeterminate number of acceptable answers and open the floor to students' ideas" (Nystand et al., 1997, p.38). In this regard, the interaction is dialogic as it recognized more than one point of views (Mortimer \& Scott, 2003). Second, the teacher managed to include students' voice in the classroom interaction by accommodating to students' responses and encouraging them to draw on their own experience in knowledge construction. From this perspective, the interaction between the teacher and students is interactive as the teacher valued students' views and took account of them (Mortimer \& Scott, 2003). Third, the teacher questions shifted the authority for evaluating answers to students, and made students directly respond to each other's answers. Hence, they create a dialogic and interactive atmosphere in the classroom interaction.

The teacher formulated questions in ways that are in line with some of the features of Communicative Language Teaching (CLT) method. In the first place, with regard to instructional objectives, the observed classroom interaction achieved the "integrative and content level", and the "linguistic and instrumental level" (Piepho, 1981). In other words, students used English as a means of expression and saw English paradoxes an object of learning. Next, as students are expected to interact with other people according to CLT (Richards \& Rodgers, 2001), students were expected to articulate their thoughts and thinking with effective and appropriate linguistic resources for the purpose of getting opinions across to the teacher and fellow students in the observed classroom interaction. Then, in accordance to Howatt's (1984) "weak" version of CLT which suggests an integration of communication activities into a wider program of language teaching, the observed teacher-and-student interaction is embedded in the larger classroom instruction of paradox. Though the interaction described above is not targeted at developing communicative competence (Richards \& Rodgers, 2001), its dialogic and interactive nature created opportunities for students to use English to communicate with the teacher and peers. It is through communication that students learned to interpret and use paradoxes.

\section{Task-based-Language-Teaching-oriented teacher questioning}

The teacher questioning analyzed above shows how the teacher engaged students in the task of comprehending of paradoxes through successive questions. In this sense, the lesson is based on Task-based Language Teaching (TBLT) 
method, which defines task as "classroom work which involves learners in comprehending, manipulating, producing or interacting in the target language" (Nunan, 1989, p.10). What is special for the observed lesson is that English is both the content of learning and the media of learning. In other words, English was used as the means of learning the content - the lexical knowledge of the English language. This is because the lesson was given to English major students, whose goal is not only mastering English as communication tool, but also learning the linguistic knowledge of the English language. The other task-based feature reflected in the observed lesson is that it focused on meaning rather than form (Richards \& Rodgers, 2001). In the interaction students made grammatical mistakes. For example, S10 used adjective "pure" as an answer to the teacher's elicitation question "he may have some kind of", which actually requires nouns or noun phrases. Students produced semantically inappropriate sentences like "I think this situation depends on different subjects". However, all these grammatical mistakes and semantic ambiguities were not corrected by the teacher, as they did not prevent the teacher and students from exchanging meanings. Thus, its focus on meaning but not form aligns the lesson with TBLT. Moreover, the teacher's efforts in building students' thinking in higher-order level instead of eliciting one pre-determined short answer at lower-order thinking make the lesson correspond with TBLT, which suggests a focus on process rather than product (Feez, 1998).

\section{REFERENCES}

[1] Belenky, M., Clinchy, B., Goldberger, N., \& Tarule, J. (1986). Women's ways of knowing: The development of self, voice, and mind. New York: Basic Books.

[2] Carlsen, W. (1991). Questioning in classrooms: A sociolinguistic perspective. Review of Education Research 61.2, 157-178.

[3] Chin, C. (2007). Teacher questioning in science classrooms: Approaches that stimulate productive thinking. Journal of Research in Science Teaching 44.6, 815-843.

[4] Feez, S. (1998). Text-based syllabus design. Sydney: National Center for English Teaching and Research.

[5] Howatt, A. (1984). A history of English language teaching. Oxford: Oxford University Press.

[6] Johnson, P., Woodside-Jiron, H., \& Day, J. (2001). Teaching and learning literate epistemologies, Journal of Educational Psychology 93.1, 223-233.

[7] Mortimer, E. F. \& Scott, P. H. (2003). Meaning making in secondary science classroom. Maidenhead, HK: Open University Press.

[8] Nunan, D. (1989). Designing tasks for the communicative classroom. New York: Cambridge University Press.

[9] Nystrand, M., Gamoran, A., Kachur, R. \& Prendergast, C. (1997). Opening dialogue: Understanding the dynamics of language and learning in the English classroom. New York: Teachers College Press.

[10] Piepho, H. (1981). Establishing objectives in the teaching of English. In C. Candlin (Ed.), The communicative teaching of English: Principles and an exercise typology (pp. 45-48). London: Longman.

[11] Richards, J. \& Theodore, S. (2001). Approaches and methods in language teaching. Cambridge: Cambridge University Press.

[12] Van Zee, E. \& Minstrell, J. (1997). Using questioning to guide student think. The Journal of the Learning Sciences 6.2, 227-269.

Kelu Wang was born in Leshan, China in 1984. She received her Master of Arts in English language and literature from Sichuan University, China in 2009.

Currently she is a lecturer in the School of Foreign Languages, Leshan Normal University, China. At the same time, she is pursuing her second Master's degree at Nanyang Technological University, Singapore. Her research interests include second language acquisition, child literacy development, and teaching English as a foreign language.

Xiaolin Wang was born in Baoji, China in 1977. He finished his Master of Arts in Linguistics and Applied Linguistics at Northwestern Polytechnical University, China.

Currently he is teaching in the Faculty of Humanities and Foreign Languages, Xi'an University of Technology, China. His research interests include second language acquisition and classroom discourse analysis. 